\title{
Kualitas Jasa, Harga dan Pengaruhnya Terhadap Kepuasan Pelanggan
}

\author{
Edwar M. Nur ${ }^{* 1}$, Chairul Ichsan ${ }^{1}$ \\ ${ }^{1}$ Program Studi ilmu Manajemen Fakultas Ekonomi, Universitas Abulyatama, Aceh Besar, 23372, \\ Indonesia. \\ *Email korespondensi: edwarmnur@gmail.com ${ }^{1}$
}

Diterima 17 Februari 2018; Disetujui 18 April 2018; Dipublikasi 30 April 2018

\begin{abstract}
This business emerged in response to the demands of people who wanted an efficient form of timecare business. The need for auto repair shops and car salon in one roof has increased. Therefore the market potential of this field of business is very large. The purpose of this study is to determine the effect of service quality and price simultaneously on customer satisfaction of Sehat Workshop in Banda Aceh, to know the effect of service quality partially on customer satisfaction of Sehat Workshop in Banda Aceh and to know the effect of price partially on customer satisfaction Sehat Workshop in Banda Aceh. This research was conducted at Sehat workshop branch of Banda Aceh which is located at P.Nyak Makam Street. No.167. Lambhuk Kota Banda Aceh, while the object of this study is about the quality of service and customer satisfaction using the service of Sehat Workshop Banda Aceh, with the number of respondents as many as 150 people. The results showed that the quality of services and prices together significantly affect the satisfaction of consumers Sehat Workshop in Banda Aceh, then the quality of service products from the Sehat Workshop individually significantly affect the satisfaction of consumers of service users Sehat Workshop Banda Aceh and individually prices given by Sehat Workshop individually have an effect on significantly to customer satisfaction of service user of Sehat Workshop of Banda Aceh.
\end{abstract}

Keywords: service quality, price, customer satisfaction

\begin{abstract}
Abstrak: Bisnis ini muncul sebagai jawaban dari tuntutan masyarakat yang menginginkan suatu bentuk usaha perawatan yang efisien waktu. maka kebutuhan akan bengkel dan salon mobil yang terintegrasi dalam satu atap mengalami peningkatan. Oleh karena itu potensi pasar bidang usaha ini sangat besar. Tujuan penelitian ini adalah untuk mengetahui pengaruh kualitas jasa dan harga secara simultan terhadap kepuasan konsumen Bengkel Sehat di Banda Aceh, mengetahui pengaruh kualitas jasa secara parsial terhadap kepuasan konsumen Bengkel Sehat di Banda Aceh dan mengetahui pengaruh harga secara parsial terhadap kepuasan konsumen Bengkel Sehat di Banda Aceh. Penelitian ini dilakukan pada Bengkel Sehat Cabang Banda Aceh yang terletak di jalan P.Nyak Makam. No.167. Lambhuk Kota Banda Aceh, sedangkan objek penelitian ini adalah mengenai kualitas pelayanan dan kepuasan konsumen yang menggunakan jasa pelayanan Bengkel Sehat Banda Aceh, dengan jumlah responden sebanyak 150 orang. Hasil penelitian menunjukkan bahwa kualitas jasa dan harga secara bersama-sama berpengaruh secara signifikan terhadap kepuasan konsumen Bengkel Sehat di Banda Aceh, kemudian kualitas jasa produk dari Bengkel Sehat secara individu berpengaruh secara signifikan terhadap kepuasan konsumen pengguna jasa Bengkel Sehat Banda Aceh serta secara individu harga yang diberikan oleh Bengkel Sehat secara individu berpengaruh secara signifikan terhadap kepuasan konsumen pengguna jasa Bengkel Sehat Banda Aceh.
\end{abstract}

Kata kunci : kualitas jasa, harga, kepuasan pelanggan 
Kepuasan atau ketidakpuasan pelanggan merupakan bagian dari pengalaman pelanggan terhadap suatu produk atau jasa yang ditawarkan. Berdasarkan pengalaman yang diperolehnya, pelanggan memiliki kecenderungan untuk membangun nilai-nilai tertentu. Nilai tersebut akan memberikan dampak bagi pelanggan untuk melakukan perbandingan terhadap kompetitor dari produk atau jasa yang pernah dirasakannya (Margaretha, 2004). Apabila sebuah perusahaan memberikan produk atau jasanya yang berkualitas baik, maka diharapkan mampu memenuhi harapan pelanggan dan akhirnya mampu memberikan nilai yang maksimal serta menciptakan kepuasan bagi pelanggan dibanding kompetitor-kompetitor yang ada.

Pelanggan diibaratkan seorang raja yang harus dilayani, namun hal ini bukan berarti menyerahkan segala-galanya kepada pelanggan. Usaha memuaskan kebutuhan pelanggan harus dilakukan secara menguntungkan atau bersifat "winwin situation" yaitu dimana kedua belah pihak merasa senang atau tidak ada yang dirugikan. Kepuasan pelanggan merupakan suatu hal yang sangat berharga demimempertahankan keberadaan pelanggannya tersebut untuk tetap berjalannya suatu bisnis atau usaha.

Salah satu bisnis atau usaha yang juga merasakan ketatnya persaingan saat ini adalah bisnis Bengkel Sehat. Persaingan yang semakin ketat tersebut ditandai dengan makin banyaknya bengkelbengkel bermunculan di kota Banda Aceh. Pelayanan dan harga yang ditawarkan pun beraneka macam, dengan begitu akan menjadi ciri dan keunggulan tersendiri bagi setiap bengkel. Hal tersebut menuntut pihak pemilik atau pengelola bengkel untuk menciptakan strategi agar mampu bersaing dan unggul.

Dengan semakin meningkatnya persaingan yang ada, perusahaan harus mengetahui faktor-faktor yang mempengaruhi kepuasan pelanggannya agar dapat melakukan perbaikan dan inovasi yang diharapkan dapat meningkatkan kepuasan pelanggan setelah melakukan transaksi di Bengkel Sehat Banda Aceh dan juga harus diperhatikan oleh perusahaan dengan menganalisis keluhan-keluhan pelanggan, seperti misalnya pengerjaan atau reparasi mobil yang terkadang memakan waktu relatif lama dan hasil akhir yang terkadang kurang memenuhi permintaan pelanggan. Pihak perusahaan juga harus mampu memahami keinginan-keinginan pelanggannya serta mempelajari faktor-faktor yang dapat mempengaruhi kepuasan para pelanggannya.

Tujuan Penelitian adalah Untuk mengetahui pengaruh kualitas pelayanan dan harga secara simultan terhadap kepuasan pelanggan. Disamping itu juga untuk mengetahui pengaruh kualitas pelayanan dan harga secara partial terhadap kepuasan pelanggan.

Penelitian ini menjelaskan tentag kepuasan pelanggan dipengaruhi oleh kualitas jasa dan harga. Untuk membantu dalam memahami penelitian, diperlukan adanya suatu kerangka pemikiran sebagai berikut :

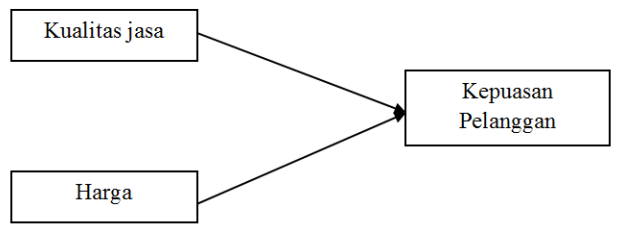

Gambar 1. Kerangka pemikiran 


\section{Hipotesis}

Berdasarkan uraian latar belakang dan permasalahan serta teori dan kerangka pemikiran di atas, maka yang menjadi hipotesis dalam penelitian ini adalah :

Ho- $-1_{1}=$ Kualitas Jasa dan Harga tidak berpengaruh signifikan terhadap kepuasan pelanggan pada Bengkel Sehat Banda Aceh.

$\mathrm{H}_{1-1}=$ Kualitas Jasa dan Harga berpengaruh signifikan terhadap kepuasan pelanggan pada Bengkel Sehat Banda Aceh.

$\mathrm{Ho}_{-2}=$ Kualitas Jasa tidak berpengaruh signifikan terhadap kepuasan pelanggan pada bengkel Sehat Banda Aceh.

$\mathrm{H}_{1-2}=$ Kualitas Jasa berpengaruh signifikan terhadap kepuasan pelanggan pada bengkel Sehat Banda Aceh.

$\mathrm{Ho}_{-3}=$ Harga tidak berpengaruh signifikan terhadap kepuasan pelanggan pada Bengkel Sehat Banda Aceh.

$\mathrm{H}_{1-3}=$ Harga berpengaruh signifikan terhadap kepuasan pelanggan pada Bengkel Sehat Banda Aceh.

\section{METODOLOGI PENELITIAN}

\section{Populasi dan sampel}

Seluruh pelanggan adalah populasi. Sampel dalam penelitian ini adalah keseluruhan dari pelanggan yang berjumlah 70 orang.

\section{Skala Pengukuran Variabel}

Instrument dalam penelitian ini adalah kuesioner, yaitu pertanyaan yang dibuat sedemikian rupa hingga responden dibatasi dalam memberi jawaban kepada beberapa alternatif saja. Sedangkan penyusunan skala pengukuran digunakan Skala Likertt, dengan alternatif pilihan 1 sampai dengan 5 jawaban pertanyaan dengan ketentuan sebagai berikut :

Tabel 1 Skala Likert

\begin{tabular}{|c|c|c|c|c|}
\hline $\begin{array}{c}\text { Sangat } \\
\text { Tidak } \\
\text { Setuju } \\
\text { (STS) }\end{array}$ & $\begin{array}{c}\text { Tidak } \\
\text { Setuju } \\
\text { (TS) }\end{array}$ & $\begin{array}{c}\text { Kurang } \\
\text { Setuju } \\
(\mathrm{KS})\end{array}$ & $\begin{array}{c}\text { Setuju } \\
(\mathrm{S})\end{array}$ & $\begin{array}{c}\text { Sangat Setuju } \\
(\mathrm{SS})\end{array}$ \\
\hline 1 & 2 & 3 & 4 & 5 \\
\hline
\end{tabular}

\section{Analisis Regresi Linier Berganda}

Adapun metode analisis data digunakan untuk menjawab hipotesis penelitian yaitu, untuk mengetahui pengaruh Kualitas Jasa Dan Harga Terhadap Kepuasaan Pelanggan adalah dengan analilis regresi linier berganda dengan bantuan program SPSS versi 20. Dengan persamaan sebagai berikut :

$\mathrm{Y}=\alpha+\beta_{1} \mathrm{X}_{1}+\beta_{2} \mathrm{X}_{2}+\varepsilon$

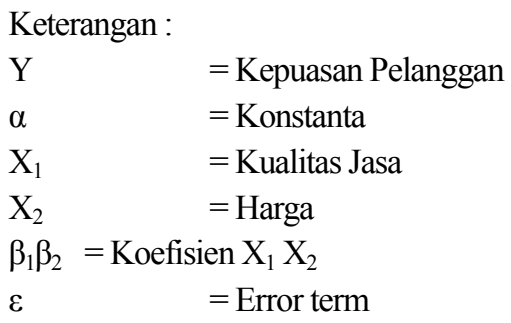

\section{Uji-F (Uji Simultan)}

Uji F merupakan pengujian terhadap koefisien regresi secara bersama-sama yaitu pengaruh dari seluruh variable independen $(\mathrm{X})$ terhadap variable dependen (Y). Adapun kriteri pengambilan keputusannya adalah :

a. Jika $F_{\text {hitung }}>F_{\text {tabel, }}$ maka menolak Ho dan menerima $\mathrm{Ha}$, artinya kualitas jasa dan harga secara bersama-sama berpengaruh signifikan terhadap kepuasan pelanggan Bengkel Sehat Banda Aceh.

b. Jika $\mathrm{F}_{\text {hitung }}<\mathrm{F}_{\text {tabel, }}$ maka menerima Ho dan menolak Ha, artinya kualitas jasa dan harga 
secara bersama-sama tidak berpengaruh signifikan terhadap kepuasan pelanggan Bengkel Sehat Banda Aceh.

\section{Uji-t (Uji Parsial)}

Uji t digunakan untuk menguji hipotesis secara parsial guna menunjukkan pengaruh tiap variabel independen secara individu terhadap variable dependen. Pengujian ini akan membandingkan hasil perhitungan $t_{\text {hitung }}$ dengan $t_{\text {tabel. Adapun kriteri }}$ pengujian hipotesis untuk uji-t adalah :

a. Jika $t_{\text {hitung }}>t_{\text {tabel, }}$ maka menolak Ho dan menerima Ha, artinya kualitas jasa dan harga secara parsial berpengaruh signifikan terhadap kepuasan pelanggan Bengkel Sehat Banda Aceh.

b. Jika $\mathrm{t}_{\text {hitung }}<\mathrm{t}_{\text {tabel, }}$ maka menerima Ho dan menolak $\mathrm{Ha}$, artinya kualitas jasa dan harga secara parsial tidak berpengaruh signifikan terhadap kepuasan pelanggan Bengkel Sehat Banda Aceh.

\section{HASIL DAN PEMBAHASAN}

\section{Gambaran Umum Bengkel Sehat Cabang}

\section{Banda Aceh}

Bengkel Sehat adalah perusahaan yang memfokuskan diri pada perawatan mobil dengan konsep utama adalah look new \& wet look. Atas dasar konsep ini, Bengkel Sehat berusaha memberikan perawatan mobil terbaik sehingga mobil-mobil pelanggan akan tampak seperti baru setelah keluar dari Bengkel Sehat.

Dengan menggunakan obat-obatan dan bahanbahan berkualitas, peralatan canggih, dan SDM yang terlatih dan telah di training secara intensif di Bengkel Sehat Prioritas (Training Center), di sini mobil pelanggan akan di maintenain dengan profesional. Servis perawatan mobil di Bengkel Sehat meliputi: Cuci Snow \& Ice Cream, Cuci Poles Snow \& Ice Cream, Medical Treatment (Salon Mobil Auto Glym ${ }^{\mathrm{TM}}+$ Bengkel Sehat), Spa Massage for Your Car, Anti gores.

\section{Kualitas}

Kualitas merupakan evaluasi menyeluruh pelanggan atas kebaikan kinerja atribut barang atau jasa, sebagaimana dijelaskan pada tabel 1. Dari data tersebut menunjukkan bahwa konsumen merasa puas terhadap kualitas produk dari Bengkel Sehat Cabang Banda Aceh, hal ini mengindikasikan bahwa konsumen merasa puas terhadap variabel yang diteliti dengan diperoleh nilai rata-rata keseluruhan (rerata) sebesar 4.05. Hal ini juga dapat dilihat dari beberapa item pernyataan dari responden mengenai kualitas pelayanan Bengkel Sehat relatif lebih unggul dibandingkan dengan merek lain, pelayanan Bengkel Sehat selalu memenuhi harapan konsumen, bengkel Sehat merupakan pelayanan jasa servis yang sudah terkenal, dan Bengkel Sehat mempunyai pelayanan yang berbeda dengan produk jasa lain.

Tabel 2 Persepsi Terhadap Kualitas Jasa

\begin{tabular}{|c|c|c|c|c|c|c|c|c|c|c|c|c|}
\hline \multirow[t]{2}{*}{ No. } & \multirow[t]{2}{*}{ Variabel } & \multicolumn{2}{|c|}{$\begin{array}{l}\text { Sgt Tdk } \\
\text { Puas }\end{array}$} & \multicolumn{2}{|c|}{$\begin{array}{l}\text { Tdk } \\
\text { Puas }\end{array}$} & \multicolumn{2}{|c|}{ Netral } & \multicolumn{2}{|c|}{ Puas } & \multicolumn{2}{|c|}{ Sgt Puas } & \multirow{2}{*}{$\begin{array}{l}\text { Rata- } \\
\text { Rata }\end{array}$} \\
\hline & & Fr & $\%$ & Fr & $\%$ & Fr & $\%$ & Fr & $\%$ & Fr & $\%$ & \\
\hline 1. & Kualitas pelayanan Bengkel & & & & & & & & & & & \\
\hline & $\begin{array}{l}\text { Sehat relatif lebih unggul } \\
\text { dibandingkan dengan merek lain }\end{array}$ & 2 & 1,3 & 0 & 0.0 & 7 & 4.7 & 77 & 51.3 & 66 & 44.0 & 4.39 \\
\hline 2. & $\begin{array}{l}\text { Pelayanan Bengkel Sehat selalu } \\
\text { memenuhi harapan konsumen }\end{array}$ & 1 & 0,7 & 0 & 0.0 & 9 & 6.0 & 100 & 66.7 & 41 & 27.3 & 4.21 \\
\hline 3. & Bengkel Sehat merupakan & 3 & 2,0 & 2 & 1.3 & 37 & 24.7 & 90 & 60.0 & 21 & 14.0 & 3.87 \\
\hline
\end{tabular}

Kualitas Jasa, Harga dan Pengaruhnya.... 


\begin{tabular}{|c|c|c|c|c|c|c|c|c|c|c|c|c|}
\hline \multirow[t]{2}{*}{ No. } & \multirow[t]{2}{*}{ Variabel } & \multicolumn{2}{|c|}{$\begin{array}{l}\text { Sgt Tdk } \\
\text { Puas }\end{array}$} & \multicolumn{2}{|c|}{$\begin{array}{l}\text { Tdk } \\
\text { Puas }\end{array}$} & \multicolumn{2}{|c|}{ Netral } & \multicolumn{2}{|r|}{ Puas } & \multicolumn{2}{|c|}{ Sgt Puas } & \multirow{2}{*}{$\begin{array}{l}\text { Rata- } \\
\text { Rata }\end{array}$} \\
\hline & & Fr & $\%$ & $\mathbf{F r}$ & $\%$ & Fr & $\%$ & Fr & $\%$ & Fr & $\%$ & \\
\hline 4. & $\begin{array}{l}\text { pelayanan jasa servis yang sudah } \\
\text { terkenal } \\
\text { Bengkel Sehat mempunyai } \\
\text { pelayanan yang berbeda dengan } \\
\text { produk jasa lain }\end{array}$ & 2 & 1,3 & 2 & 1.3 & 61 & 40.7 & 72 & 48.0 & 15 & 10.0 & 3.67 \\
\hline \multicolumn{2}{|c|}{ Rerata } & & & & & & & & & & & 4.05 \\
\hline
\end{tabular}

\section{Harga}

Harga merupakan sejumlah uang yang dibebankan atas suatu produk atau jasa atau jumlah dari nilai yang ditukar konsumen atas manfaatmanfaat karena memiliki atau menggunakan produk atau jasa tersebut, sebagaimana dijelaskan pada tabel 3. Berdasarkan tabel tersebut dapat dijelaskan bahwa harga yang diberikan oleh Bengkel Sehat Cabang Banda Aceh, hal ini dapat dilihat dari persepsi responden terhadap indikator harga dengan diperoleh nilai rata-rata keseluruhan (rerata) sebesar
3.21 .

Hal ini menunjukkan yang telah ditetapkan memberikan dampak terhadap keputusan pembelian konsumen, dimana dapat dilihat dari beberapa pernyataan responden mengenai harga yang ditawarkan oleh Bengkel Sehat cenderung bervariasi, banyak usaha perawatan mobil yang memberikan diskon terhadap beberapa produk pelayanan, dan saya memilih Bengkel Sehat karena sangat ekonomis dan terjangkau.

\section{Tabel 3 Persepsi Terhadap Harga}

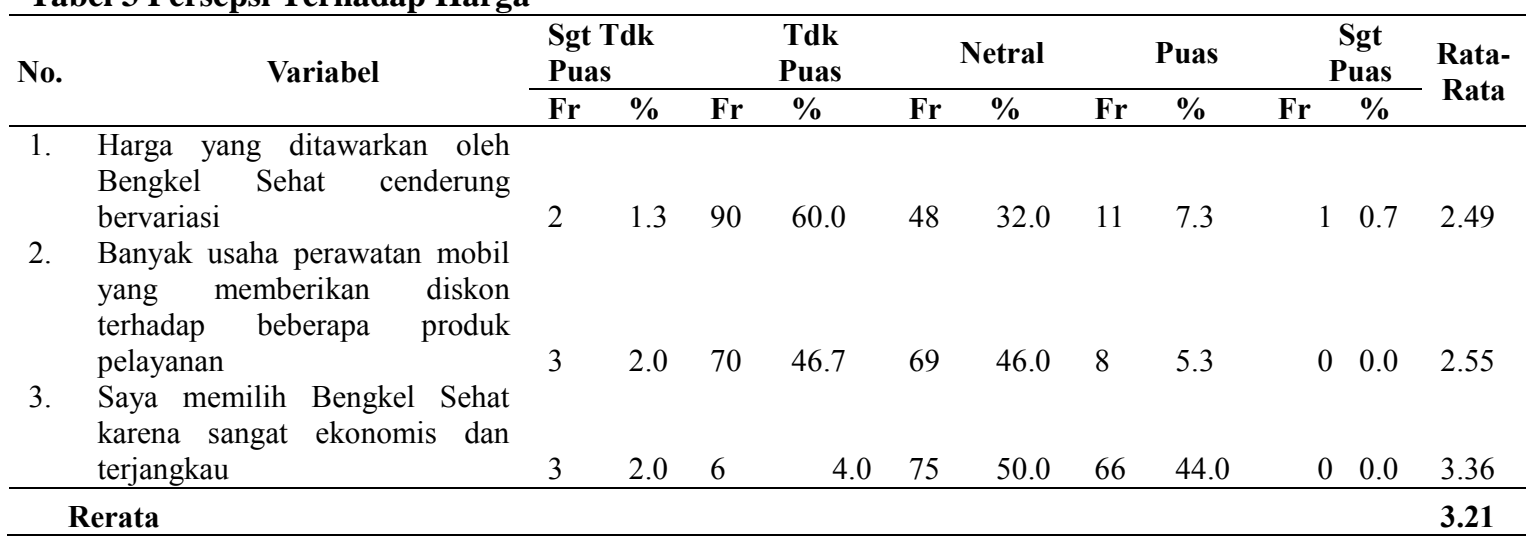

\section{Kepuasan Pelanggan}

Kepuasan Pelanggan merupakan perasaan senang atau kecewa seseorang yang berasal dari perbandingan antara kesannya terhadap kinerja (hasil) sesuatu produk dengan harapannya., sebagaimana dijelaskan pada tabel 4. Berdasarkan tabel tersebut dapat dijelaskan bahwa kepuasan pelanggan bengkel sehat, hal ini tercermin dari nilai rata-rata keseluruhan (rerata) dari variabel tersebut, dengan diperoleh nilai rerata sebesar 3.72 , atau konsumen mempunyai melakukan kepuasan pelanggan Bengkel Sehat sudah cukup tinggi. Hal ini juga dapat dilihat dari beberapa item pernyataan responden terutama mengenai responden memilih Bengkel Sehat, karena adanya sikap dari orang lain, responden melakukan kepuasan pelanggan Bengkel 
Sehat karena adanya faktor situasional, responden melakukan kepuasan pelanggan Bengkel Sehat karena brand image tersebut telah melekat dalam benak responden dan responden memutuskan memilih Bengkel Sehat karena kualitas produk pelayanan yang diberikan sangat bagus.
Analisis Pengaruh Kualitas Jasa dan Harga

\section{Terhadap Kepuasan Konsumen}

Seperti yang dikemukakan pada perumusan masalah dan hipotesis. Maka penelitian ini menganalisis pengaruh kualitas jasa $\left(\mathrm{X}_{1}\right)$, harga $\left(\mathrm{X}_{2}\right)$ sebagai variabel bebas (independen variabel) terhadap kepuasan pelanggan Bengkel Sehat Cabang Banda Aceh sebagai variabel terikat (dependent variabel) baik secara simultan maupun parsial.

Tabel 4. Kepuasan Pelanggan

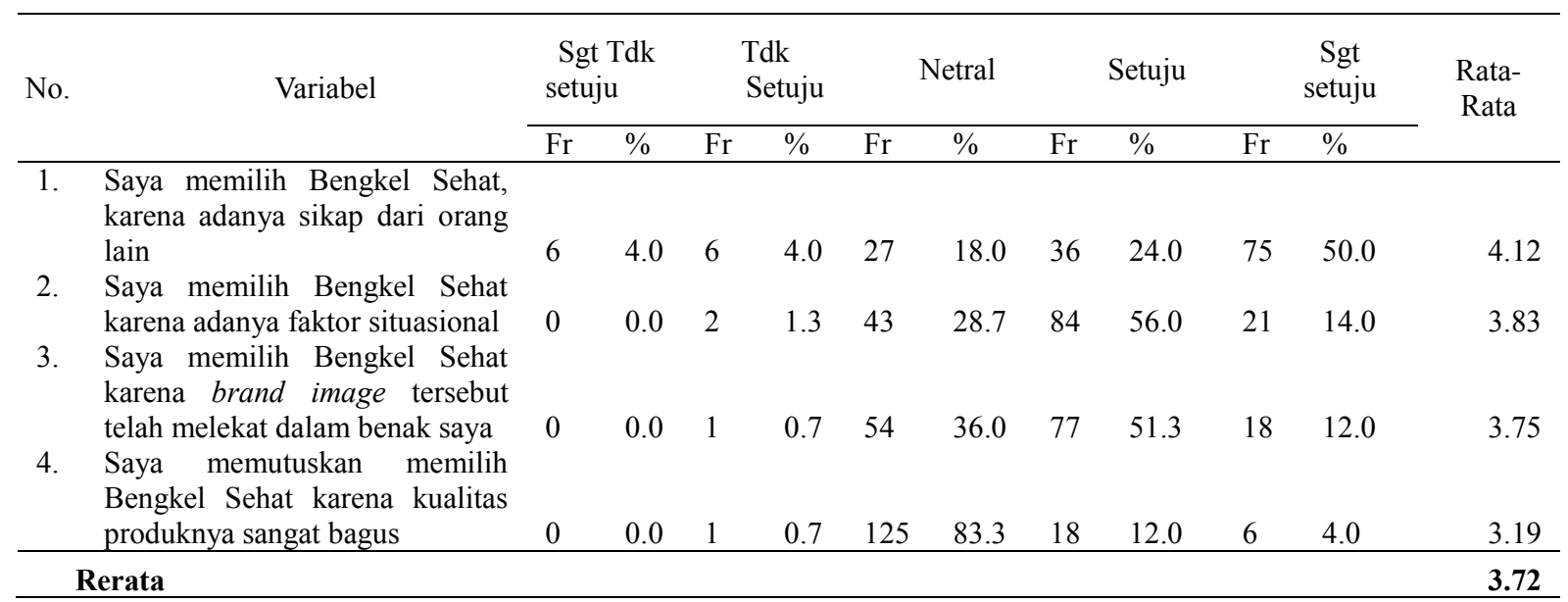

Dalam rangka mengetahui kepuasan pelanggan Bengkel Sehat dan pengaruhnya terhadap kepuasan maka perlu diketahui pengaruh variabel bebas yaitu variabel kualitas jasa $\left(\mathrm{X}_{1}\right)$, variabel harga $\left(\mathrm{X}_{2}\right)$, terhadap kepuasan pelanggan (Y) Bengkel Sehat Cabang Banda Aceh. Pengaruh masing-masing variabel bebas terhadap variabel terikat secara terinci dapat dilihat pada tabel 5 .

\section{a. Pengujian Secara Serentak (Uji-F)}

Untuk menguji hipotesis mengenai variabel Independent dalam hubungan dengan kepuasan pelanggan, maka dapat dijelaskan pada tabel 5 berikut ini:
Tabel 5. Hubungan kualitas jasa dan harga terhadap kepuasan konsumen

\begin{tabular}{lcccccc}
\hline Model & $\begin{array}{l}\text { Sum of } \\
\text { Squares }\end{array}$ & df & $\begin{array}{l}\text { Mean } \\
\text { Squares }\end{array}$ & F $_{\text {hitung }}$ & F $_{\text {Tabel }}$ & Sig. \\
\hline Regresi & 12.995 & 3 & 4.332 & 23.361 & 2.666 & 0.00 \\
& & & & & & $0^{\mathrm{a}}$ \\
Sisa & 27.072 & 146 & 0.185 & & & \\
\hline Total & $\mathbf{4 0 . 0 6 7}$ & $\mathbf{1 4 9}$ & & & & \\
\hline
\end{tabular}

Hasil pengujian secara simultan diperoleh $\mathrm{F}_{\text {hitung }}$ sebesar 23.361, sedangkan $\mathrm{F}_{\text {Tabel }}$ pada tingkat signifikansi $\propto=5 \%$ adalah sebesar 2.666. Hal ini memperlihatkan bahwa $F_{\text {hitung }}>F_{\text {Tabel, }}$ dengan tingkat probabilitas 0.000 . Dengan demikian hasil perhitungan ini dapat di ambil suatu keputusan bahwa menerima hipotesis alternatif dan menolak 
hipotesis nol, artinya bahwa variabel faktor kualitas jasa (x1), faktor harga (x2), secara bersama-sama berpengaruh secara signifikan terhadap kepuasan pelanggan Bengkel Sehat Cabang Banda Aceh, dengan demikian terbukti bahwa terdapat pengaruh yang signifikan antara faktor kualitas jasa (x1), dan faktor harga (x2) terhadap kepuasan pelanggan Bengkel Sehat Cabang Banda Aceh, dengan demikian hipotesis alternatif (Ha) yang diajukan diterima dan menolak hipotesis nol (Ho), karena diperoleh nilai $\mathrm{F}_{\text {hitung }}>\mathrm{F}_{\text {Tabel, }}$ dengan tingkat probabilitas 0.000

\section{b. Hasil Uji-t (Secara Parsial)}

Untuk menguji faktor-faktor yang mempunyai pengaruh terhadap kepuasan pelanggan secara parsial (setiap variabel) dapat dilihat dari hasil uji-t. Hasil perhitungan yang diperlihatkan pada Tabel IV.9, dimana dapat diketahui besarnya $t_{\text {hitung }}$ untuk masing-masing variabel dengan tingkat kepercayaan atau signifikansi sebesar $\alpha=5 \%$.

\section{Analisis Kualitas Jasa Terhadap Kepuasan Pelanggan}

Hasil penelitian terhadap variabel kualitas jasa diperoleh $t_{\text {hitung }}$ sebesar 4.301, sedangkan $t_{\text {Tabel }}$ sebesar 1.976, hasil perhitungan ini menunjukkan bahwa $t_{\text {hitung }}>t_{\text {Tabel }}$ dengan signifikansi sebesar 0.000 atau probabilitas jauh dibawah $\square=5 \%$. Dengan demikian hasil perhitungan statistik menunjukkan bahwa secara parsial variabel kualitas berpengaruh secara signifikan terhadap kepuasan pelanggan Bengkel Sehat Cabang Banda Aceh, dengan demikian hipotesis Hal diterima dan menolak hipotesis Hol. Hasil penelitian ini mengindikasikan bahwa kualitas jasa yang diberikan oleh Bengkel Sehat Cabang Banda Aceh kepada para pelanggannya akan dapat memberikan tingkat kepuasan tersendiri bagi para konsumennya. Kualitas jasa yang diberikan oleh Bengkel Sehat Cabang Banda Aceh kepada para pelanggan meliputi tentang pengetahuan karyawan Bengkel Sehat Cabang Banda Aceh terutama mengenai kehandalan (reliability) yaitu adanya konsistensi kerja dan kemampuan untuk di percaya oleh konsumen. Hal ini berarti Bengkel Sehat Cabang Banda Aceh memberikan jasanya secara tepat kemudian ketanggapan yaitu kemauan atau kesiapan para karyawan untuk memberikan jasa yang di butuhkan pelanggan, adanya keyakinan yang diberikan oleh Bengkel Sehat Cabang Banda Aceh kepada pelanggan, kemudian sikap empati yaitu kemudahan dalam menjalin relasi, komunikasi yang baik, perhatian pribadi dan pemahaman terhadap kebutuhan individual para pelanggan serta wujud pelayanan yaitu penampilan fisik perlengakapan, pegawai dan sarana komunikasi.

\section{Analisis Harga Terhadap Kepuasan Pelanggan}

Hasil penelitian terhadap variabel harga diperoleh $t_{\text {hitung }}$ sebesar 3.194 sedangkan $t_{\text {Tabel }}$ sebesar 1.976, hasil perhitungan ini menunjukkan bahwa $\mathrm{t}_{\text {hitung }}>\mathrm{t}_{\text {Tabel, }}$, dengan tingkat signifikansi sebesar 0.002 atau probabilitas jauh diatas $\square=5 \%$. Berdasarkan hasil perhitungan statistik menunjukkan bahwa secara parsial variabel harga berpengaruh secara signifikan terhadap kepuasan pelanggan Bengkel Sehat Cabang Banda Aceh, dengan demikian hipotesis $\mathrm{Ha} 2$ diterima dan menolak hipotesis Ho2.

Untuk membuktikan hipotesis alternatif bahwa terdapat pengaruh secara langsung antara faktor- 
faktor yang diteliti berpengaruh secara signifikan terhadap kepuasan pelanggan melalui kualitas jasa (x1), dan harga (x2), hal ini dapat dilihat dari nilai $t_{\text {hitung }}>t_{\text {Tabel }}$ dengan tingkat signifikansi sebesar 0.000 atau probabilitas jauh dibawah $\square=5 \%$.

Berdasarkan hasil penelitian dapat dijelaskan bahwa semua indikator yang diteliti berpangaruh terhadap kepuasan pelanggan Bengkel Sehat Cabang Banda Aceh, dimana kualitas jasa (x1), harga (x2), sangat berpengaruh terhadap kepuasan pelanggan Bengkel Sehat Cabang Banda Aceh.

Sedangkah hasil pengujian secara parsial disebutkan bahwa bahwa kualitas jasa (x1), dan harga (x2), mempunyai pengaruh secara signifikan terhadap kepuasan pelanggan Bengkel Sehat Cabang Banda Aceh, dengan demikian hipotesis Hal dan $\mathrm{Ha} 2$ diterima dan menolak hipotesis Ho1, dan Ho2.

Sedangkan penelitian yang penulis lakukan menyebutkan bahwa kualitas jasa (x1), harga (x2), sangat berpengaruh terhadap kepuasan pelanggan Bengkel Sehat Cabang Banda Aceh, hal ini mengindikasikan bahwa seorang konsumen yang ingin membeli produk yang ditawarkan oleh Bengkel Sehat Cabang Banda Aceh sangat memperhatikan terhadap faktor kualitas, harga dari Bengkel Sehat Cabang Banda Aceh tersebut serta atribut pembelian dari Bengkel Sehat Cabang Banda Aceh tersebut, dimana ketiga variabel tersebut ternyata sangat mempengaruhi kepuasan pelanggan terhadap Bengkel Sehat Cabang Banda Aceh tersebut.

\section{KESIMPULAN DAN SARAN}

\section{Kesimpulan}

Berdasarkan hasil penelitian sebagaimana telah dijelaskan pada bab IV dan V, maka pada bab ini dijelaskan mengenai kesimpulan dan saran, sebagaimana dijelaskan berikut ini:

a. Hasil pengujian menunjukkan bahwa kualitas jasa dan harga secara bersama-sama berpengaruh secara signifikan terhadap kepuasan konsumen Bengkel Sehat di Banda Aceh

b. Berdasarkan hasil penelitian ini diperoleh penjelasan bahwa variabel kualitas jasa produk dari Bengkel Sehat secara individu berpengaruh secara signifikan terhadap kepuasan konsumen pengguna jasa Bengkel Sehat Banda Aceh.

c. Kemudian hasil penelitian juga menunjukkan bahwa harga yang diberikan oleh Bengkel Sehat secara individu berpengaruh secara signifikan terhadap kepuasan konsumen pengguna jasa Bengkel Sehat Banda Aceh.

\section{Saran}

a. Setelah melakukan penelitian ini Bengkel Sehat Banda Aceh memang sangat diminati masyarakat, oleh karena itu hendaknya dapat lebih meningkatkan pelayanan kepada konsumen terutama dalam meningkatkan kualitas pelayanan yang diberikan kepada pelanggan, sehingga pelanggan menjadi puas dengan pelayanan yang diberikan.

b. Harga yang ditawarkanpun kepada pelanggan bervariatif, oleh karena itu semua bentuk atau jenis produk pelayanan yang ditetapkan oleh Bengkel Sehat hendaknya dapat dipertahankan mengingat semakin banyaknya usaha-usaha 
bengkel yang menyedian jasa pelayanan tersebut, sehingga harga yang ditawarkan Bengkel Sehat Banda Aceh lebih terjangkau kepada masyarakat dibandingkan bengkel yang lain.

c. Perlu adanya sosialisasi tentang standar pelayanan yang akan diberikan kepada pelanggan, sehingga pelanggan akan mudah mengetahui tentang standar pelayanan yang akan diberikan oleh Bengkel Sehat Banda Aceh, sehingga pelayanan yang akan diterima oleh sesuai dengan harapan konsumen.

\section{DAFTAR PUSTAKA}

Arikunto, Suharsimi. (2002). Statistik Konsep Dasar Aplikasi. Jakarta: Kencana Pranada Pranada Media.

Dhammesta. Basu Swastha dan Irawan. (2000). Manajemen Pemasaran Moderen. Yogyakarta : Liberty.

Ghozali, Imam. (2006). Aplikasi Analisis Multivariate Dengan Program SPSS. Semarang: Badan Penerbit Universitas Diponegoro.

Jasfar, Farida. (2005). Manajemen JasaPendekatan Terpadu. Bogor: Ghalia Indonesia.

Kotler dan Armstrong. (2001). Prinsip-Prinsip Pemasaran, Jakarta: Erlangga.

Sugiyono. (2004). Metode Penelitian Bisnis. Bandung: Alfabetha.

Lalu Zulhendri. (2009). Pengaruh kualitas pelayanan terhadap kepuasan nasabah shar-E di Yogyakarta. Yogyakarta.

Lupiyoadi, Rambat. (2001). Manajemen
Pemasaran Jasa-Teori dan Praktek.

Jakarta: Salemba Empat.

Marzuki. (2005). Metodologi Riset. Yogyakarta: Ekonisia.

Nasution. (2004). Manajemen Jasa Terpadu. Bogor Selatan: Graha Indonesia.

Sumayang. Lalu. (2003). Dasar-dasara Manajemen Produksi dan Operasi. Jakarta: Salemba Empat.

Tjiptono, Fandy. (2001). Strategi Pemasaran. Yogyakarta: Andi.

Tjiptono, Fandy. (2004). Pemasaran Jasa, Malang: Bayumedia.

Tjiptono, Fandy dan Gregorius Chandra. (2005). Service, Quality and Satisfaction, Yogyakarta: ANDI.

Widiyanto, Ibnu, 2008, Pointers: Metodologi Penelitian, Semarang: Badan Penerbit Universitas Diponegoro

Widarjono. Agus. (2005). Ekonometrika Teori dan Aplikasi untuk Ekonomi dan Bisnis. Yogyakarta: Ekonisia.

- How to cite this paper:

M. Nur, E., \& Ichsan, C. (2018). Kualitas Jasa, Harga dan Pengaruhnya Terhadap Kepuasan Pelanggan pada Bengkel Sehat Banda Aceh. Jurnal Humaniora, 2(1), 10 18. 